\title{
Decisão interlocutória declinatória de competência recorrível por agravo de instrumento: análise interpretativa do art. 1.015 do Código de Processo Civil
}

\author{
Interlocutory decision declining competence for appeal due to interlocutory appeal: interpretative \\ analysis of art. 1.015 of the Code of Civil Procedure
}

Decisión interlocutoria de declinación de la competencia de recurso por recurso interlocutorio: análisis interpretativo del art. 1.015 del Código de Procedimiento Civil

\section{Resumo}

O presente artigo trata da recorribilidade das decisões interlocutórias expressa no Código de Processo Civil, que passou a prever hipóteses de decisões interlocutórias definitivas de mérito, decisões interlocutórias provisórias de mérito e decisões interlocutórias. A problematização encontra-se na interpretação inicial de taxatividade do Art. 1.015 do CPC, que prevê a recorribilidade por Agravo de Instrumento das decisões interlocutórias expressas e as que não estariam expressas no rol do referido artigo deveriam ser suscitadas em preliminar de apelação, sendo cabível, para fins de evitar a preclusão, o protesto, com base no Art. 278, do CPC/2015 ou a impetração de Mandado de Segurança. Contudo, recentemente o Superior Tribunal de Justiça entendeu que é cabível o Agravo de instrumento contra decisão interlocutória que julga matéria de incompetência, haja vista a interpretação então mitigada do Art. 1.015 do $\mathrm{CPC} / 2015$. Para o constructo argumentativo utiliza-se da metodologia dedutiva em análise à doutrina, jurisprudência e legislação pertinente à matéria.

Palavras-chave: Taxatividade do Art. 1.015; Decisão interlocutória definitiva de mérito; Decisão interlocutória provisória de mérito; Decisões interlocutórias processuais; Agravo de instrumento; Mitigação.

\begin{abstract}
This article deals with the appeal of interlocutory decisions expressed in the Code of Civil Procedure, which now provides for hypotheses of definitive interlocutory decisions on merits, provisional interlocutory decisions on merits and interlocutory decisions. The problematization is found in the initial interpretation of taxativity of Art. 1.015 of the CPC, which provides for the appeal by an Interlocutory Appeal of the interlocutory decisions expressed and those that would not be expressed in the list of the referred article should be raised in a preliminary appeal, being appropriate, for purposes of avoiding the preclusion, the protest, in Art. 278, CPC/2015 or the writ of mandamus. However, recently the Superior Court of Justice understood that the interlocutory appeal against an interlocutory decision that judges a matter of incompetence is appropriate, given the then mitigated interpretation of Art. 1.015 of CPC/2015. For the argumentative construct, deductive methodology is used in the analysis of doctrine, jurisprudence and legislation relevant to the matter.
\end{abstract}

Keywords: Taxativeness of Art. 1,015; Final interlocutory decision on the merits; Provisional interlocutory decision on the merits; Interlocutory procedural decisions; Interlocutory appeal; Mitigation.

\section{Resumen}

Este artículo trata sobre la apelación de las decisiones interlocutorias expresadas en el Código de Procedimiento Civil, que ahora prevé hipótesis de decisiones interlocutorias definitivas sobre el fondo, decisiones interlocutorias sobre el fondo y decisiones interlocutorias. La problematización se encuentra en la interpretación inicial de la taxatividad del Art. 1.015 del CPC, que prevé que la apelación mediante Recurso Interlocutorio de las decisiones interlocutorias expresadas y las que no quedarían expresadas en la lista del referido artículo deberán plantearse en apelación 
preliminar, en su caso, a los efectos de evitar la preclusión, la protesta, basada en el Art. 278, CPC/2015 o el auto de mandamus. Sin embargo, recientemente la Corte Superior de Justicia entendió que procede el recurso interlocutorio contra una decisión interlocutoria que juzga un asunto de incompetencia, dada la entonces atenuada interpretación del Art. 1.015 de CPC/ 2015. Para el constructo argumentativo se utiliza la metodología deductiva en el análisis de la doctrina, jurisprudencia y legislación relevante en la materia.

Palavras clave: Taxatividad del Art. 1.015; Decisión final interlocutoria sobre el fondo; Decisión interlocutoria provisional sobre el fondo; Decisiones procesales interlocutorias; Apelación interlocutoria; Mitigación.

\section{Introdução}

A atividade do operador do direito pela sistemática do Código de Processo Civil de 1973 era a de identificar os provimentos jurisdicionais descritos no Art. 162, do CPC/1973 e verificar qual o recurso cabível. De acordo com a legislação anterior, contra qualquer decisão interlocutória era cabível o recurso de agravo de instrumento ou retido.

A partir dessa premissa, a legislação contemporânea expressa as principais alterações, sendo certo que somente as decisões interlocutórias elencadas no Art. 1.015, do CPC/2015, poderão ser atacadas pelo agravo de instrumento. Assim, se a decisão interlocutória não estiver prevista no referido dispositivo legal, será enfrentada na preliminar do recurso de Apelação.

Logo, pelo Código de Processo Civil de 2015, entende-se que muitas matérias não ficarão mais preclusas tendo em vista a possibilidade da apresentação do protesto do Art. 278, bem como a impetração do mandado de segurança caso seja inútil aguardar o julgamento da ação, no caso, por exemplo da decisão declinatória de competência.

No entanto, o posicionamento recente da Corte Superior do Tribunal de Justiça, defendeu que a natureza jurídica do rol do Art. 1.015, do CPC/2015 é de taxatividade mitigada, sendo, portanto, agravável as decisões interlocutórias para além das situações previstas no referido texto legal.

Assim sendo, será realizada a análise descritiva das teorias dos julgados e a fixação do precedente em relação a decisão interlocutória que julga a matéria relativa à incompetência do juízo. Resultando na interpretação de utilização do agravo de instrumento e não mais pela via do mandado de segurança.

\section{Metodologia}

O método parte da análise descritiva de premissas verdadeiras, pois provém da legislação e teorias sedimentadas até então pelo Superior Tribunal de Justiça e doutrina. Como afirma Marconi e Lakatos (2003, p. 92) o método dedutivo "tem o propósito de explicar o conteúdo das premissas", com o intuito, no presente trabalho, de sustentar de modo completo a conclusão.

Conforme Galuppo (2008, p.112), "É preciso dizer o que vai ser feito, como vai ser feito, quando, onde e por quê".

Nesse sentido, parte-se da análise da previsão legislativa em relação as decisões interlocutórias de acordo com o Código de Processo Civil de 1973 e posterior Código vigente, para entender o cabimento da interposição do agravo de instrumento.

Na sequência, precede-se a descrição interpretativa da utilização do Mando de Segurança em decorrência da intepretação advinda do Art. 1.015 do vigente CPC, para então compor a explicação do cabimento do instrumento contra decisão interlocutória declinatória de competência com base nas teorias doutrinárias e do Superior Tribunal de Justiça, destacando a teoria aplicada da mitigação. 


\section{Resultados e Discussões}

\subsection{A decisão interlocutória no código de processo civil de 1973}

O Código de Processo Civil de $1973^{1}$, também chamado de Código Buzaid, conceituou a decisão interlocutória como sendo o ato pelo qual o juiz no curso do processo resolve uma questão incidente, ou seja, não se comunica com o julgamento do mérito.

Ademais, acerca da questão incidente inserida no antigo conceito de decisão interlocutória, registra Medina (2016, p. 362):

O CPC/1973 usava a expressão "questão incidente" surgida "no curso do processo", para se referir ao objeto da decisão interlocutória (cf. comentário supra); a doutrina mais antiga, à luz da legislação então em vigor, classificava as questões que poderiam ser examinadas em decisões interlocutórias em incidentes e emergentes (se surgidas antes ou depois da contestação, mas sempre antes da sentença; cf. comentário infra).

Porquanto, a doutrina que se formou no Código de Processo Civil de 1973 tratava a correlação entre decisão de mérito e apelação bem como decisão interlocutória e agravo de instrumento como absoluta. Logo, entende-se que o conceito de decisão interlocutória foi bem mais elaborado pelo legislador do antigo Código de Processo Civil.

Nesse sentido convém destacar o entendimento do Medina (2014):

Estabelecia o artigo 162, parágrafo $1 .^{\circ}$ do CPC/1973, antes da alteração da Lei 11.232/2005: "Sentença é o ato pelo qual o juiz põe termo ao processo, decidindo ou não o mérito da causa". Com a redação que recebeu da Lei 11.232/2005, o parágrafo $1 .^{\circ}$ do artigo 162 do CPC/1973 passou a enfatizar o conteúdo da sentença, como elemento distintivo: "Sentença é o ato do juiz que implica alguma das situações previstas nos arts. 267 e 269 desta Lei”.

Ambas as descrições de sentença (a anterior à reforma de 2005, que destacava o momento da prolação do pronunciamento, e a segunda, que realçava o conteúdo da decisão) eram confrontadas com a definição de decisão interlocutória contida no parágrafo $2 .^{\circ}$ do artigo 162 do CPC/1973, que a vinculava à resolução de qualquer "questão incidente”, no curso do processo.

Medina (2016, p. 1501) elucida que "no sistema do CPC/1973, as decisões interlocutórias sujeitam-se ao recurso de agravo, que ficaria como regra, retido, admitindo-se a forma de instrumento em casos previstos em lei, e sempre que demonstrasse risco de lesão (Art. 522 do CPC/1973)".

Assim, sob o olhar automático do antigo Código de Processo Civil, havia a premissa de que contra qualquer decisão interlocutória era cabível o recurso de agravo, seja na modalidade por instrumento ou retida nos autos.

\subsection{A decisão interlocutória no código de processo civil de 2015}

A legislação expressa no vigente Código de Processo Civil afastou-se do conceito antigo de decisão interlocutória no sentido de que decisão interlocutória é todo provimento jurisdicional com carga decisória que não se enquadre no conceito de sentença. Logo, pela nova sistemática processual decisão interlocutória não é apenas uma mera questão incidental em que o magistrado resolve no curso do processo.

Com efeito, cumpre destacar o posicionamento do Medina (2016, p. 362) referente ao conceito antigo do CPC/1973:

$\mathrm{O}$ CPC/2015 não seguiu igual critério: basta que se extinga processo ou fase com pronunciamento com fundamento nos arts. 485 ou 487 do CPC/2015 para que se esteja diante de sentença, sendo que, nos demais casos, haverá decisão interlocutória, seja a questão incidente, emergente ou superveniente à própria sentença. A "fase", aqui, não se deve atribuir o mesmo sentido que largamente era empregado pela doutrina, para designar as fases processuais postulatória,

\footnotetext{
${ }^{1}$ Art. 162. Os atos do juiz consistirão em sentenças, decisões interlocutórias e despachos. § 2o Decisão interlocutória é o ato pelo qual o juiz, no curso do processo, resolve questão incidente.
} 
saneatória, instrutória e decisória (cf., a respeito, comentário ao art. 319 do CPC/2015); refere-se o legislador a "fase" de conhecimento (ou de cognição) em oposição à de cumprimento (ou de execução)

O legislador, no Art. 203, no momento em que conceituou os provimentos jurisdicionais e definiu o que seria uma sentença, dispõe no parágrafo $1^{\circ}$ : "ressalvadas as disposições expressas dos procedimentos especiais, sentença é o pronunciamento por meio do qual o juiz, com fundamento nos $\underline{\text { Arts. } 485} \mathrm{e} \underline{487}$, põe fim à fase cognitiva do procedimento comum, bem como extingue a execução". E no parágrafo $2^{\circ}$ desse mesmo dispositivo legal, já inclui a definição do que seria uma decisão interlocutória deixando claro que se determinado provimento jurisdicional não se enquadrar no conceito de sentença nos termos da lei, ela será considerada como uma decisão interlocutória.

Segundo Neves (2016, p. 347):

O Art. 203, $\S 2^{\circ}$ do Novo CPC optou por um conceito residual de decisão interlocutória, prevendo-a como qualquer pronunciamento decisório que não seja sentença. Nesse caso a decisão interlocutória poderá ter como conteúdo questões incidentais ou mérito, como ocorre, por exemplo, no julgamento antecipado parcial de mérito.

Medina (2016, p. 361-362) afirma que: "vê-se que o conceito legal de sentença é restritivo. Já o conceito legal de interlocutória é extensivo: não é sentença, mas interlocutória, a decisão que não se enquadrar na descrição do $\S 1^{\circ}$ do Art. 203 do CPC/2015 (cf. § $2^{\circ}$ do mesmo artigo)".

Com efeito, entende-se que a atual legislação considerou o critério por exclusão para definir a decisão interlocutória, afirmando que esta é todo pronunciamento do juiz que não se classifica como sentença e tem um conteúdo decisório, já que os despachos, seguindo a sequência do código de processo civil no parágrafo $3^{\circ}$, do Art. 203, seria apenas um ato de impulso processual sem um conteúdo decisório.

\subsubsection{Decisões interlocutórias definitivas de mérito}

Uma das principais inovações do atual Código de Processo Civil foi o Art. 356, que trata do julgamento antecipado parcial do mérito. Logo, no caso em que o magistrado decidir parcialmente o mérito, contra essa decisão, o recuso cabível será o Agravo de Instrumento, nos termos do parágrafo $5^{\circ}$ do mesmo artigo.

Sobre o tema, Medina (2016, p.630) registra:

É correto afirmar, no regime do CPC2015, que a decisão que julga parte dos pedidos (decisão parcial), embora diga respeito ao mérito, não é sentença. (...). Não é correto, também, afirmar-se que no caso há "sentença parcial", embora seja possível falar em decisão parcial (em oposição à decisão global, que será sempre sentença). Como algum(ns) do(s) pedido(s), ou parcela dele(s) restara(m) sem julgamento, prossegue-se o procedimento até que se chegue à sentença, que julgará todos os pedidos (decisão global) ou o último deles (porque daí, tal decisão será final). A respeito, cf. comentário ao art. 203 do CPC/2015. Contra a decisão proferida com base no art. 356 do CPC/2015 cabe agravo de instrumento.

Destarte, sob a análise desse dispositivo legal é conditio sine qua non para que que haja a interposição do Agravo de Instrumento que a decisão interlocutória seja de mérito, ou seja, exista um fatiamento da análise do mérito pelo magistrado na fase de conhecimento.

Neste sentido destaca Assumpȩãe Neves (2016, p. 1559): “O Art. 356, § 5º do Novo CPC, prevê cabimento de agravo de instrumento contra decisão interlocutória que julgar parcialmente o mérito, em hipótese já contemplada pelo Art. 1.015, II, do Novo CPC". Elucida ainda: 
no inciso II está a confirmação expressa e indiscutível da admissão pelo sistema da decisão interlocutória de mérito, recorrível por agravo de instrumento. Tradicionalmente, a revisão da decisão de mérito era feita pelo recurso de apelação. No Novo Código de Processo Civil caberá também agravo de instrumento na hipótese de decisão interlocutória de mérito e de julgamento antecipado parcial de mérito. (Neves, 2016, p. 1562).

Cumpre ressaltar ainda a decisão interlocutória parcial de mérito na hipótese de instauração de incidente de desconsideração da personalidade jurídica, prevista no Art. 1.015, IV, do Código de Processo Civil de 2015.Quando a decisão interlocutória tem esse conteúdo, entende-se que essa decisão é de mérito pelo fato de estar auferindo a possível responsabilidade ou o afastamento da responsabilidade do patrimônio do sócio da empresa.

\subsubsection{Decisões interlocutórias provisórias de mérito}

Dentro da fase de conhecimento é necessário verificar o conteúdo das decisões interlocutórias, sendo o provimento jurisdicional condicionado à apreciação da tutela provisória, tem-se uma decisão interlocutória provisória de mérito recorrível por agravo de instrumento. Como alerta Medina (2016, p. 1332) "quanto à decisão que defere ou indefere liminar em mandado de segurança, encarta-se na hipótese prevista no Art. 1.015, I, do CPC/2015".

Por fim, outra situação equiparada a de tutela provisória, é a possibilidade de interpor agravo de instrumento da decisão que concede, modifica ou revoga o efeito suspensivo aos embargos à execução, nos termos do Art. 1.015, X, do Código de Processo Civil.

\subsubsection{Decisões interlocutórias processuais}

É certo afirmar que as hipóteses de decisões interlocutórias processuais estão elencadas em numerus clausus nos demais incisos do artigo 1.015, do Código de Processo Civil.

Neste sentido, destacam-se os incisos do referido dispositivo legal, que assim dispõem:

Art. 1.015. Cabe agravo de instrumento contra as decisões interlocutórias que versarem sobre:

(...);

III - rejeição da alegação de convenção de arbitragem;

$(\ldots)$

$\mathrm{V}$ - rejeição do pedido de gratuidade da justiça ou acolhimento do pedido de sua revogação;

VI - exibição ou posse de documento ou coisa;

VII - exclusão de litisconsorte;

VIII - rejeição do pedido de limitação do litisconsórcio;

IX - admissão ou inadmissão de intervenção de terceiros;

(...);

XI - redistribuição do ônus da prova nos termos do art. $373, \S 1^{\text {o; }}$;

$(\ldots)$;

XIII - outros casos expressamente referidos em lei.

Desta feita, examinadas as três formas de decisões interlocutórias trazidas pelo Novo Código de Processo Civil, pode-se concluir que a sistemática de enfrentamento dessas decisões foi redimensionada, ou seja, somente aquelas que estiverem elencadas no art. 1.015 do CPC/2015, podem ser impugnadas pelo recurso de agravo de instrumento.

Por sua vez, caso as decisões interlocutórias não estiverem presentes na lista do referido dispositivo legal, entendese que poderão ser atacadas nas preliminares do recurso de apelação. Neste caso, pelo novo sistema processual, é cabível, numa primeira oportunidade, promover um protesto com base no art. 278, do CPC/2015², sob pena de preclusão.

Acerca do protesto previsto em lei, é o posicionamento do Medina (2016, p. 459):

\footnotetext{
${ }^{2}$ Art. 278. A nulidade dos atos deve ser alegada na primeira oportunidade em que couber à parte falar nos autos, sob pena de preclusão.
} 
O mesmo ocorre, mutatis mutandis, à luz do CPC/2015: $1^{\circ}$ ) não alegado o vício na primeira oportunidade em que lhe couber falar nos autos, restará o ato convalidado (salvo no caso do parágrafo único do art. 278 do CPC/2015, cf. comentário supra); $2^{\circ}$ ) a alegação do vício - chamada de "protesto" na praxe trabalhista - é necessária para que haja decisão a respeito da questão, que, se não impugnável por agravo de instrumento, o será através de apelação interposta contra a sentença (cf. art. 1.009, $\S 1^{\circ}$ do CPC/2015)

Contudo, há que se registrar que a nova sistemática processual permite a possibilidade da interposição do mandado de segurança contra decisão interlocutória não agravável quando não for possível à parte prejudicada aguardar o momento de interposição do recurso de apelação para discutir o pronunciamento judicial.

Extrai-se das lições de Nery Junior e Nery (2015, p. 2078):

Pode se dizer que o sistema abarca o princípio da irrecorribilidade em separado das interlocutórias como regra. Não se trata de irrecorribilidade da interlocutória que não se encontra no rol do CPC 1015, mas de recorribilidade diferida, exercitável em futura e eventual apelação (razões ou contrarrazões). Entretanto, se a interlocutória tiver potencialidade de causar imediato gravame de difícil ou impossível reparação, de tal sorte que não possa esperar seja exercida a pretensão recursal como preliminar de apelação, pode ser, desde logo, submetida ao exame do tribunal competente para conhecer da apelação, pelo exercimento do mando de segurança e da correição parcial.

Destarte, destaca-se, em especial, a decisão judicial sobre competência, da qual caberá o mandado de segurança em razão do direito líquido e certo da parte de ter seu pleito sendo processado pelo órgão jurisdicional incompetente, nos termos do Art. 5, LXIX, da Constituição Federal.

Dessa forma, demanda compreender que, teoricamente, pela lógica da taxatividade do Art. 1.015 do CPC/2015, somente caberá agravo de instrumento contra decisões interlocutórias definitivas de mérito, decisões interlocutórias provisórias de mérito e decisões interlocutórias processuais, sendo que nas situações de decisões irrecorríveis por agravo de instrumento, poderá a parte prejudicada fazer o protesto do Art. 278 do CPC/2015 ou impetrar o recurso de mandado de segurança.

Assim é o entendimento do Superior Tribunal de Justiça acerca do cabimento do mandado de segurança:

EMENTA. RECURSO ORDINÁRIO EM MANDADO DE SEGURANÇA. ATO JUDICIAL. EXCEPCIONALIDADE CONFIGURADA. MANIFESTA ILEGALIDADE. TERCEIRO PREJUDICADO (SÚMULA N. 202/STJ). RECURSO PROVIDO. SEGURANÇA CONCEDIDA.

1. Fora das circunstâncias normais, a doutrina e a jurisprudência majoritárias admitem o manejo de mandado se segurança contra ato judicial, ao menos nas seguintes hipóteses excepcionais: a) decisão judicial manifestamente ilegal ou teratológica; b) decisão judicial contra a qual não caiba recurso; c) para imprimir efeito suspensivo a recurso desprovido de tal atributo; e d) quando impetrado por terceiro prejudicado por decisão judicial.

2. Na espécie, o ato judicial apontado como coator mostra-se teratológico, pois, ausente de fundamentação jurídica, deferiu, contra terceiro estranho à lide, sem o mínimo de contraditório, pedido de restituição de valores sem sequer cogitar de ouvir a instituição financeira impetrante acerca da origem e titularidade dos ativos financeiros reclamados, contrariando os princípios do contraditório, da ampla defesa e da motivação, colorários do Devido Processo Legal.

3. Incidência da Súmula n. 202/STJ: "A impetração de segurança por terceiro, contra ato judicial, não se condiciona a interposição de recurso ".

4. Recurso provido para conceder a segurança, cassando-se o ato apontado como coator.

Isso posto, entende-se que caberá o manejo do writ diante da ausência de possibilidade de impugnação da decisão judicial que declinou da competência por agravo de instrumento.

\section{Anterior Interpretação de Aplicabilidade do Mandado de Segurança}

Por tudo que foi exposto até agora, ficou demonstrado que o Art. 1015 do CPC prevê as hipóteses que cabem agravo de instrumento, sendo esse rol taxativo. 
No CPC/2015, as decisões interlocutórias não impugnáveis de imediato por agravo de instrumento, poderão ser impugnadas através das razões de apelação ou contrarrazões (Art. 1.009, § $1^{\circ}$ do CPC/2015).

Ressalta-se que no vigente Código não existem decisões interlocutórias irrecorríveis, e sim, decisões interlocutórias recorríveis de imediato, e outras que poderão ser impugnadas posteriormente, por meio de preliminar de apelação.

Assim, a problemática se encontra na necessidade de esperar o recurso de apelação para impugnar essas decisões não recorríveis por meio de agravo, o que diante da notória morosidade do poder judiciário pode acarretar em ônus a parte e comprometer a efetividade do processo. Nesses casos, a única medida processual cabível seria o manejo do writ afim de evitar possíveis prejuízos no curso do processo, demonstrando que o legislador ao taxar as hipóteses do Art. 1015, deixou de prever outra forma mais eficaz e célere de impugnar essas decisões não agraváveis no momento em que são expedidas.

Assim, quando presente a situação que gera risco de graves danos, deve ser admitido o mandado de segurança.

De acordo com Medina (2016, p. 1334):

Deve-se admitir o mandado de segurança como sucedâneo do agravo de instrumento contra decisões interlocutórias proferidas em $1^{\circ}$ grau de jurisdição, à luz do Código de Processo Civil de 2015, sempre que se demonstrar a inutilidade do exame do ato acoimado de ilegal apenas por ocasião do julgamento da apelação.

A respeito, Medina \& Araújo, ensinam que "deve-se admitir o mandado de segurança quando a lei dispuser que em determinada hipótese não caberá recurso" (Medina \& Araújo, 2009, p. 77).

Sobre o Mandado de Segurança, importante dizer que se trata de um remédio constitucional previsto no art. $5^{\circ}$, inciso LXIX da Constituição Federal ${ }^{3}$ e regulamentado pela Lei 12.016/09, ou seja, de acordo com o ensinamento de Medina e Araújo (2009, p. 21):

O mandado de segurança é uma ação civil que constitui uma garantia constitucional individual e coletiva para a tutela dos direitos fundamentais relativo às liberdades públicas albergados pelo art. $5^{\circ}$ da $\mathrm{CF} / 88$. Seu manejo está indissociavelmente atrelado ao status activus processualis e é manifestação do direito de resistência do cidadão contra os atos ilegais e abusivos praticado pelo poder público"

Desse modo, é perfeitamente cabível o mandado de segurança contra decisões interlocutórias não agraváveis, considerando-o como sucedâneo do agravo de instrumento quando ficar demonstrado a inutilidade ou o risco do resultado por ocasião do julgamento da apelação.

Nota-se que o legislador não previu isso ao taxar o rol do Art. 1.015 do CPC, pois existem casos que não estão previstos neste rol e que não teriam como aguardar a prolação da sentença para impugnar o ato por meio das razões de apelação. É o que pode ocorrer, por exemplo, no caso de ser declinada a competência, tal decisão não está prevista no rol do agravo de instrumento e não se pode impor a parte aguardar a sentença para impugnar por meio de preliminar de apelação, admitindo-se, neste caso, o mandado de segurança.

Nesse sentido importante registrar trecho da decisão do Tribunal Regional Federal da $4^{\text {a }}$ Região que admitiu o mandado de segurança contra decisão declinatória de competência, no Mandado de Segurança ${ }^{\circ}$ 000054965.2017.4.04.0000/PR:

Decido. De início, apenas a título de elucidação, consigno que, à luz da Lei do Mandado de Segurança e da Súmula 267 do STF, somente deve ser admitido o mandado de segurança na ausência de possibilidade de impugnação da

\footnotetext{
${ }^{3}$ Art. 5o, da CF: LXIX - conceder-se-á mandado de segurança para proteger direito líquido e certo, não amparado por "habeas-corpus" ou "habeas-data", quando o responsável pela ilegalidade ou abuso de poder for autoridade pública ou agente de pessoa jurídica no exercício de atribuições do Poder Público.
} 
decisão judicial por recurso com efeito suspensivo ou por meio de correição parcial. Na hipótese em debate, em se tratando o ato inquinado de declinação da competência, a situação dos autos não é passível de impugnação, a princípio, nem por recurso com efeito suspensivo nem mesmo por correição parcial, razão pela qual o mandado de segurança merece trânsito.

Seguindo os ensinamentos de Neves (2016, p. 1560) "seja como for, aguarda-se a popularização do mandado de segurança, que passará a ser adotado onde atualmente se utiliza do agravo quando este tornar-se incabível".

Assim sendo, "nota-se que em razão do rol taxativo do art. 1.015 trazido pelo novo legislador, a doutrina vem sustentando a possibilidade do mandado de segurança contra atos do juiz que, por exemplo declina a competência" (Mello, Ramos, Bonagura, Montans, 2016).

Conquanto o entendimento doutrinário acerca do cabimento do mandado de segurança contra decisão interlocutória declinatória de competência, haja vista o numerus clausus do rol do art. 1.015 do atual códex, a Corte Especial do Superior Tribunal de Justiça, no final de 2018, entendeu que é cabível o Agravo de instrumento contra decisões interlocutórias, sob o fundamento da taxatividade mitigada do rol do referido dispositivo legal.

\section{Agravo de Instrumento Contra Decisão Interlocutória Declinatória de Competência: Mitigação do Código de Processo Civil}

Como já dito exaustivamente, no Código de Processo Civil de 2015 não há um conceito aberto e interpretativo e argumentativo para o manejo do Agravo de Instrumento, haja vista as hipóteses taxativas previstas no Art. 1.015, as quais prescindem de demonstrar a lesão grave e de difícil reparação.

No entanto, existem situações no curso do processo que extrapolam as hipóteses do rol do referido dispositivo legal, que começaram a desafiar a advocacia tanto privada quanto pública.

Porquanto, acabou-se por implementar a possibilidade de agravar decisões judiciais para além desse dispositivo legal, demonstrando a necessidade de provimento do recurso e de manifestação do tribunal ou então o manejo do Mandado de Segurança para que o Tribunal pudesse rever determinadas decisões interlocutórias irrecorríveis por Agravo de Instrumento.

Destarte, para a definição da natureza jurídica do rol do Art. 1.015 do Código de Processo Civil foram implementadas quatro teses pela doutrina e Superior Tribunal de Justiça acerca da discussão dessa matéria processual.

A primeira foi a Teoria da Taxatividade Restrita, a qual defende que as decisões interlocutórias só podem ser atacadas por Agravo de Instrumento, tendo em vista o numerus clausus do rol do Art. 1.015 do atual códex.

Ademais conforme destacado no item anterior, parte da doutrina sustenta a tese da taxatividade, alegando ser possível o manejo do Mandado de Segurança contra ato do juiz, que, por exemplo, declina a competência.

Essa tese, inclusive, foi adotada pela Ministra Maria Thereza de Assis Moura, que iniciou a divergência acerca da discussão da natureza jurídica, pois entende que a taxatividade estabelecida pelo sistema processual é legal, e, qualquer alteração deve ser feita via Parlamento e não Poder Judiciário.

Confira-se trecho do voto-vista da Ministra Maria Thereza de Assis Moura, no Recurso Especial n. 1.704.520 - MT, em 05.12.2018:

Em que pese a percepção de que a prestação jurisdicional seria mais efetiva se algumas hipóteses não previstas no rol do art. 1.015 do Código de Processo Civil comportassem a impugnação na via do agravo de instrumento, não vejo como possível que o Poder Judiciário possa assumir a tarefa de criar novas hipóteses ao rol de decisões interlocutórias agraváveis, notadamente porque foi evidente a escolha do Poder Legislativo pelo numerus clausus. 
De outro lado, foi apresentada a Teoria do Rol Exemplificativo, segundo a qual, o rol do Art. 1.015 não possui taxatividade, a contrário sensu, é exemplificativo no sentido de que cabe Agravo de Instrumento para além das hipóteses daquele rol desde que comprovado efetivamente os requisitos de urgência e de riscos à parte.

Destarte, a Quarta Turma do Superior Tribunal de Justiça, no julgamento do Recurso Especial n. 1.679.909/RS, em 14.11.2017, iniciando-se uma flexibilização acerca da natureza jurídica do rol do Art. 1.015, entendeu que é exemplificativo, declarando ser cabível o recurso de agravo de instrumento contra decisões referente à matéria de competência.

Nesse sentido, cumpre destacar trecho do voto do Ministro Luís Felipe Salomão:

[...]. Nessa ordem de ideias, apesar de não previsto expressamente no rol do art. 1.015, penso que a decisão interlocutória, relacionada à definição de competência continua desafiando recurso de agravo de instrumento, por uma interpretação analógica ou extensiva da norma. Deveras, a possibilidade de imediata recorribilidade da decisão advém de exegese lógico-sistemática do diploma, inclusive porque é o próprio Código que determina que "o juiz decidirá imediatamente a alegação de incompetência" (§ $3^{\circ}$ do art. 64). [...]

Vislumbra-se que no meio dessas duas teses, há uma terceira, chamada de Teoria da Taxatividade passível de Interpretação Extensiva/Analógica, a qual conduz à ideia de que o rol é taxativo, porém, admite-se uma interpretação de cada inciso para permitir a hipótese de agravo de instrumento.

Nessa linha de raciocínio, Didier elucida que:

A interpretação extensiva da hipótese de cabimento de agravo de instrumento prevista no inciso III do art. 1.015 é plenamente aceitável. É preciso interpretar o inciso III do art. 1.015 do CPC para abranger as decisões interlocutórias que versam sobre competência. [...] Primeiramente em razão da identidade de ratio: são situações muito semelhantes, as quais, até mesmo pela incidência do princípio da igualdade (art. $7^{\circ}, \mathrm{CPC}$ ) não poderiam ser tratadas diferentes: alegação de convenção de arbitragem e alegação de incompetência têm por objetivo, substancialmente, afastar o juízo da causa. Ambas são formas de fazer valer em juízo o direito fundamental ao juiz natural juiz competente e imparcial, como se sabe. [...] Em terceiro lugar, qualquer decisão sobre alegação de convenção de arbitragem é impugnável, quer seja ela acolhida (apelação), quer tenha sido ela rejeitada (agravo de instrumento). A decisão que examina a alegação de incompetência é, e regra, decisão interlocutória - acolhendo-se ou rejeitando-a; o processo nãos se extingue, no máximo sendo reencaminhado ao juízo competente, caso a alegação tenha sido acolhida. Não há razão para que a alegação de incompetência tenha um tratamento não isonômico. [...] Bem pesadas as coisas, portanto, é preciso estender a hipótese do inciso III do art. 1.015 a qualquer decisão sobre a competência do juízo, seja ela relativa, seja ela absoluta (IMHOF, 2016)

Essa Interpretação Extensiva/Analógica adotada na prática da advocacia gera uma maior insegurança jurídica, pois o agravo de instrumento pode ser recebido para situações de entendimento análogo e em outros juízos como não análogo, criando nesses casos uma afronta ao princípio da isonomia. A mesma lei federal sendo aplicada de forma diferente por tribunais, em regiões e em momentos diferentes.

Ademais, adotada na prática a interpretação extensiva do agravo de instrumento, poderão surgir novas formas de preclusão imediata. Por exemplo: imagina-se que o magistrado declinou a competência do processo, e com isso, o advogado arguiu essa tese em preliminar de apelação, como ensina o Código de Processo Civil (art. 1009, §1 ${ }^{\circ}$ ). Ao ser analisado o recurso em segunda instância, o relator entende que a preliminar não deveria ser apreciada, por entender que houve preclusão imediata, por não ter agravado a decisão, sob o fundamento da interpretação extensiva.

Porquanto, essa terceira tese gera uma incerteza, abalando a segurança jurídica, pois não se sabe quando deverá agravar ou não agravar. Seguindo essa linha de raciocínio da $4^{\mathrm{a}}$ Turma do STJ, os advogados deverão agravar de todas as decisões interlocutórias, para no futuro não ter a desagradável surpresa de não ter o recurso conhecido, e por consequência, a preclusão imediata. 
Por fim, a quarta tese, inclusive, vencedora com sete votos da Corte Especial do Superior Tribunal de Justiça, no julgamento do Recurso Especial 1.704.520/MT, em 05.12.2018, foi a adotada pela Relatora Ministra Nancy Andrighi, Teoria da Taxatividade Mitigada.

De acordo com essa tese, o rol do Art. 1.015 do estatuto processual civil, é taxativo, porém admite exceções apenas excepcionais, ou seja, somente será cabível o Agravo de Instrumento quando ocorrer a inutilidade da discussão da decisão interlocutória em preliminar de apelação. Como por exemplo, a decisão declinatória de competência estudada no presente artigo.

Da análise do voto da Relatora Ministra Nancy Andrighi, entende-se que é possível o agravo de instrumento contra decisão interlocutória declinatória de competência, a partir de duas premissas.

A primeira premissa da fixação da tese em comento é da incompletude dos incisos do Art. 1.015 do CPC, e a segunda, de que as hipóteses excepcionais devem ser encaradas como excepcionalíssimas.

Nesse sentido, mister destacar trecho do voto da Ministra:

Como se percebe, o entendimento aqui exposto pretende, inicialmente, afastar a taxatividade decorrente da interpretação restritiva do rol previsto no art. 1.015 do CPC, porque é incapaz de tutelar adequadamente todas as questões em que pronunciamentos judiciais poderão causar sérios prejuízos e que, por isso, deverão ser imediatamente reexaminadas pelo $2^{\circ}$ grau de jurisdição.

Vislumbra-se que a tese da taxatividade mitigada firmada pela Ministra Nancy Andrighi foi desenvolvida pelo seguinte entendimento:

(...). A tese que se propõe consiste em, a partir de um requisito objetivo - a urgência que decorre da inutilidade futura do julgamento do recurso diferido da apelação -, possibilitar a recorribilidade imediata de decisões interlocutórias fora da lista do art. 1.015 do CPC, sempre em caráter excepcional e desde que preenchido o requisito urgência, independentemente do uso da interpretação extensiva ou analógica dos incisos do art. 1.015 do CPC, porque, como demonstrado, nem mesmo essas técnicas hermenêuticas são suficientes para abarcar todas as situações. Não há que se falar, destaque-se, em desrespeito a consciente escolha político-legislativa de restringir o cabimento do agravo de instrumento, mas, sim, de interpretar o dispositivo em conformidade com a vontade do legislador e que é subjacente à norma jurídica, qual seja, o recurso de agravo de instrumento é sempre cabível para as "situações que, realmente, não podem aguardar rediscussão futura em eventual recurso de apelação".

(...)

Em última análise, trata-se de reconhecer que o rol do art. 1.015 do CPC possui uma singular espécie de taxatividade mitigada por uma cláusula adicional de cabimento, sem a qual haveria desrespeito às normas fundamentais do próprio CPC e grave prejuízo às partes ou ao próprio processo.

A partir desse precedente processual, o Superior Tribunal de Justiça definiu a nova hipótese de cabimento do agravo de instrumento para atacar decisão interlocutória desde que demonstrada a urgência do caso concreto, ou seja, a inviabilidade, a inutilidade de discussão do teor da decisão interlocutória em preliminar de apelação.

Em que pese o julgado em comento vai na contramão do expresso na legislação, no exercício da advocacia, a hipótese de cabimento do agravo de instrumento contra decisão declinatória de competência com base na tese da taxatividade mitigada é incontestável.

A matéria acerca da competência trata-se de uma inutilidade processual, visto que no momento em que o magistrado declina a sua competência, é inútil para o processo em termos de duração razoável, que esse seja remetido para outro juízo, e em preliminar de apelação a parte demonstra que o juiz inicial é o competente.

Logo, resta clarividente que a inutilidade da decisão interlocutória em preliminar de apelação prejudica o interesse do processo, como dito, a razoável duração do processo. 
Outrossim, ressalta-se que a Corte Especial do Superior Tribunal de Justiça, com base na segurança jurídica, entendeu que somente será aplicada a teoria da taxatividade mitigada após a publicação do acordão que fixou referida tese.

Por fim, mister destacar que se a parte não interpuser o agravo de instrumento com base na taxatividade mitigada, não ocorrerá a preclusão para reapresentar o argumento da competência em sede de apelação, visto o caráter excepcionalíssimo das exceções, com definiu a Corte Superior na segunda premissa da fixação da tese mencionada acima.

Todavia se houve a interposição do agravo de instrumento e este foi indeferido, entende-se que obrigatoriamente, a decisão interlocutória declinatória de competência, é indiscutível em sede de preliminar de apelação.

Porquanto, nota-se por óbvio que diante da insatisfação da taxatividade das hipóteses do Art. 1.015 do CPC/2015, em especial, acerca da matéria processual relacionada a competência, a Corte Especial do Superior Tribunal de Justiça, pacificou o entendimento de que deve se incluir no referido rol, a hipótese de declinação de competência, com base na teoria da taxatividade mitigada.

\section{Considerações Finais}

Durante o transcorrer do presente trabalho, analisamos o conceito de decisão interlocutória e as quais estão previstas no Art. 1.015 do CPC, sendo este rol taxativo. Estudamos também as decisões que são recorríveis de imediato e as que não são recorríveis de imediato, sendo que neste último caso é possível o manejo do mandado de segurança, com o escopo de evitar prejuízos às partes, tudo conforme visto alhures.

Contudo, em que pese o rol do Art. 1.015 do CPC tenha nascido taxativo no sistema processual civil, a Corte Especial do Superior Tribunal de Justiça, após o julgamento do Recurso Especial n. 1.704.520/MT, em 05.12.2018, pela Relatora Ministra Nancy Andrighi, fixou uma nova hipótese de cabimento de agravo de instrumento.

A partir de 2018, com base na teoria da taxatividade mitigada do referido rol, construída pela jurisprudência da Corte Superior, é cabível o recurso de agravo de instrumento contra decisões declinatórias de competência desde que comprovada a inutilidade da decisão interlocutória em preliminar de apelação e seja prejudicial ao interesse do processo, como dito, a razoável duração do processo.

Diante dessa decisão, a Corte Especial do Superior Tribunal de Justiça afastou a ideia de incerteza jurídica a marcha processual, trazida pela $4^{\text {a }}$ Turma da Corte Superior, que entendeu que o rol do Art. 1.015 do CPC era exemplificativo.

Conclui-se, portanto, que após esse precedente processual, o mandado de segurança não é mais a melhor ferramenta processual para atacar decisão interlocutória declinatória de competência e sim o agravo de instrumento, contudo, apenas em certas ocasiões, como forma de evitar danos às partes, quando o resultado do processo se tornar inútil ou ineficaz.

\section{Referências}

Agravo de instrumento pode questionar competência. (2017). Consultor Jurídico. https://www.conjur.com.br/2017-nov-24/agravo-instrumento-questionarcompetencia-juizo.

Cardoso. O. V. Agravo de instrumento: rol taxativo ou exemplificativo? https://jus.com.br.

Gajardoni, F. F. O Novo CPC não é o que queremos que ele seja. https://www.jota.info.

Galuppo, M.C. (2008). Da ideia à defesa: monografias e teses jurídicas. (2a ed.). Mandamentos.

Imhof. C. Agravo de instrumento - Mudanças descritas no Novo CPC (Artigo 1.015). Saiba como o Novo CPC disciplinou o cabimento do recurso de agravo de instrumento e como os tribunais têm interpretado o rol taxativo do artigo 1.015. Recuperado de: https://blog.sajadv.com.br/novo-cpc-agravo-deinstrumento.

Mandado de Segurança n ${ }^{\circ}$ 0000549-65.2017.4.04.0000/PR. (2017). Relator: Amaury Chaves de Athayde. Tribunal Regional Federal da $4^{\mathrm{a}}$ Região. https://www2.trf4.jus.br.

Marconi, M.de A., Lakatos, E.M. (2003). Fundamentos de Metodologia Científica. (5a ed.). 
Research, Society and Development, v. 10, n. 4, e6710413920, 2021

(CC BY 4.0) | ISSN 2525-3409 | DOI: http://dx.doi.org/10.33448/rsd-v10i4.13920

Medina, J. M. G., Araújo, F. C. (2009). Mandado de Segurança Individual e Coletivo: comentários à Lei 12.016. Revista dos Tribunais.

Medina, J. M. G. (2014). Os Novos Conceitos de sentença e decisão interlocutória no novo CPC. https://www.conjur.com.br/2014-set-08/processo-novosconceitos-sentenca-decisao-interlocutoria-cpc.

Medina, J. M. G. (2016) Direito Processual Civil Moderno. (2a ed.), Revista dos Tribunais.

Medina, J. M.G. (2016). Novo Código de Processo Civil Comentado. (4a ed.), Revista dos Tribunais.

Nery Junior, N., Nery, R. M. A. (2008). Código de Processo Civil Comentado. (10a ed.), Revista dos Tribunais.

Nery Junior, N., Nery, R. M. A. (2015). Comentários ao Código de Processo Civil. 2. Tiragem. Revista dos Tribunais.

Neves, D. A. А. (2016). Manual de Direito Processual Civil. (8a ed.), JusPodivm.

Recurso em Mandado de Segurança no 49.020-SP. (2015). Relator: Raul Araújo. Superior Tribunal de Justiça. http://www.stj.jus.br/.

Recurso Especial no 1.704.520/ MT. (2018) Relatora: Nancy Andrighi. Superior Tribunal de Justiça. http://www.stj.jus.br/.

Recurso Especial no 1.679.909/RS. (2017). Relator: Luis Felipe Salomão. Superior Tribunal de Justiça. http://www.stj.jus.br/.

Mello, R L. T., Ramos. F. S., Bonagura, A. P., Montans, R. (2016). O agravo de instrumento e o rol do art. 1.015 do novo CPC: taxatividade? http://www.migalhas.com.br 